\title{
Geminatization in Torajan Language
}

\author{
Resnita Dewi ${ }^{1 *}$, Daud Rodi Palimbong ${ }^{2}$
}

\author{
I*Department of Indonesian Language Education, Faculty of Teacher Training and Education, Indonesia Christian \\ University Toraja, Tana Toraja, Indonesia \\ ${ }^{2}$ Department of Indonesian Language Education, Faculty of Teacher Training and Education, Indonesia Christian \\ University Toraja, Tana Toraja, Indonesia \\ Corresponding author. resnita@ukitoraja.ac.id
}

\begin{abstract}
This research aims to describe geminatization in The Toraja language. This research is qualitatively descriptive. Data collected by (1) observation techniques, namely observing the use of Toraja language in the Tana Toraja region, (2) recording techniques, namely recording the use of Toraja language in the Tana Toraja region, (3) recording speeches that have been recorded in the Tana Toraja region. The results showed that in the Toraja language in the Tana Toraja region, there is geminatization $\mathrm{t}$ to/ $\mathrm{tt} /$ for example in the words lettek, kalitting, mettia' mattanan, mettiro, mattunu, kandotti' malottong, geminatization $\mathrm{p}$ into /pp/ the word paleppeng, leppang, mangippi, manipping, and geminatization /k/ become /kk/on the word kekke, ma'likka, mekkayok, makkali, marekko'.
\end{abstract}

Keywords: geminatization, Toraja language

\section{INTRODUCTION}

\subsection{Phoneme}

Phonemes are the smallest language elements. Phonemes are distinguished over vowels, consonants, and semi vocals. Vowels are the sounds of language whose air currents do not encounter resistance. In vocal formation, there is no articulation. The barrier to vocal sounds is only on the vocal cords. Barriers to the vocal cords are not commonly called articulation. Consonants are phonemes formed by inhibiting air currents in some of the devices. In this case, there is articulation. Semivocal sound is a sound that practically includes consonants, but because at the time of disarticulation has not formed a pure consonant.

\subsection{Geminatization}

One of the interesting discussions related to the sound of language is geminatization. Hasibuan, et al. (2019:2) Geminat is a secondary rule for explaining the consonant duplication process. This rule of course accompanies other changes contained in the change of ethylene. Furthermore, Savitri [1] et al. added that Geminat is the same series of articulation (identical), thus giving rise to a long speech in the sound. Example of innovation: [opung] = [oppung] father/mother parents [tingkos] $=$ [tikkos] correct.
Geminat is different from homorgan [2]. Phonetically, gaminat is the same series of true (identical) articulations giving rise to contoid lengthening; Homorgan is a language sound formed with the same articulation tools or regions, but with a somewhat different way of working. For example, the sound [t] and [d] are homorgan sounds because they are both apiko-dental, but there is a difference, namely not making a sound and making a sound.

Crystal in Savitri [1] states that gemination is a sequence of contiguous identical segments in a single morpheme. In line with The Crystal, Sofyan [1]) also states that there is a twin sound or geminasi between the phonemes of the end of the previous tribe and the initial phonemes of the tribe afterwards in Madura, both in the form of basic forms and those that occur due to affixation.

Crystal and Sofyan [7] opinion is different from the opinion of Clark and Yallop (1995), geminasi is a consonant lengthening that is often treated as an order that cannot be side by side. In the spelling system, double letters are used to represent vocal lengthening (Clark and Yallop, 1995). Pycha in Savitri [1] states that geminasi is a long speech sound that contrasts with other short sounds and in many languages that have geminasi imposed restrictions on the environment of gemination [3]. That restriction is that a single consonant cannot turn into a 
geminat when surrounded by other consonants either on the right or left of the consonant [3]. It was also stated by Zainudin et al. [4], geminasi in Madura phonetically and phonemic is one sound only caused by the elongation of consonant sounds at the limit of the label, for example,/la $\square: e ? /$ 'sky'.

Geminatization is very much found in the Toraja language. Toraja is one of the regional languages in Indonesia. Toraja language is a language used by the Toraja tribe spread in Tana Toraja Regency, North Toraja Regency, and Mamasa Regency. Toraja still has several dialects in Tana Toraja regency, which is divided into three dialects, namely Makale-Rantepao dialect, SaluputtiBonggakaradeng dialect, and Sillanan-Gandangbatu dialect. In its daily use, many geminatization is found in the Toraja language.

\section{METHODOLOGY}

This research is qualitatively descriptive [5]. Data obtained in the Tana Toraja region is collected by (1) observation techniques, namely observing the use of Toraja language in the Tana Toraja region, (2) recording the use of Toraja language in the Tana Toraja region, (3) recording speech techniques that have been recorded in the Tana Toraja region [6].

\section{ANALYSIS}

Geminatization in Toraja language can be seen in the following data1.

\section{1. /t/ becomes /tt/}

Geminatization / $/ \mathrm{t} /$ being $\mathrm{tt}$ refers to the understanding of the process of duplicating consonants $/ \mathrm{t} / \mathrm{to} / \mathrm{tt} /$. In the Toraja language, there are words that in pronunciation, often the community performs the process of geminatization / $t /$. It is characterized by the presence of a word that has only one consonant $/ \mathrm{t} /$, but by society, /t/ is duplicated or duplicated so that it becomes /tt/ in its pronunciation. This appears in the following data.

\begin{tabular}{|c|c|c|}
\hline \multicolumn{2}{|c|}{ Geminatization } & \multirow{2}{*}{ Meaning } \\
\hline Gloss & Articulation & \\
\hline$[$ Lentek $]$ & Lettek & Foot \\
\hline$[$ kalinting $]$ & kalitting & Worm \\
\hline$[$ mentia $]$ & {$[$ mettia $]$} & Fly \\
\hline$[$ mantanan $]$ & {$[$ mattanan $]$} & Plant \\
\hline$[$ mentiro $]$ & {$[$ mettiro $]$} & See \\
\hline$[$ mantunu $]$ & {$[$ mattunu $]$} & Burn \\
\hline$[$ malontong $]$ & {$[$ malottong $]$} & Black once \\
\hline
\end{tabular}

Figure 1 Geminatitation /t/ becomes /tt/

\section{2. /p/ becomes /pp/}

Further geminatization in Toraja language is also seen in $/ \mathrm{p} /$ to be $/ \mathrm{pp} /$. Geminatization refers to the understanding of the process of duplicating consonants $/ \mathrm{p} /$ to $/ \mathrm{pp} /$. Similar to geminatization $/ \mathrm{t} /$ to $/ \mathrm{tt} /$, in Toraja language there are also words that in pronunciation, often experience geminatization / p / . It is characterized by the presence of a word that has only one consonant /p/, but by society, /p/ is duplicated or duplicated so that it becomes $/ \mathrm{pp} /$ in its pronunciation. This is seen in the following data

\begin{tabular}{|c|c|c|}
\hline \multicolumn{2}{|c|}{ Geminatization } & \multirow{2}{*}{ Meaning } \\
\hline Gloss & Articulation & \\
\hline$[$ palempeng $]$ & {$[$ paleppeng $]$} & Shoulder \\
\hline$[$ Lempang $]$ & {$[$ Leppang $]$} & Turn \\
\hline$[$ mangimpi $]$ & {$[$ mangippi $]$} & Bermimoi \\
\hline$[$ manimping $]$ & {$[$ manipping $]$} & Thin \\
\hline
\end{tabular}

Figure 2. Geminatitation /p/ becomes $/ \mathrm{pp} /$

\section{3./k/ becomes $/ \mathrm{kk} /$}

Geminatization $/ \mathrm{k} /$ to $/ \mathrm{kk} /$ is also found in the Toraja language. Similar to the previous two geminatizations, geminatization $/ \mathrm{k} /$ is the process of duplicating consonants $/ \mathrm{k} /$ to $/ \mathrm{kk} /$. It is characterized by the presence of a word that has only one consonant $/ \mathrm{k} /$, but by the community, $/ \mathrm{kk} /$ is duplicated or duplicated so that it becomes $/ \mathrm{tt} /$ in its pronunciation. This appears in the following data.

\begin{tabular}{|c|c|c|}
\hline \multicolumn{2}{|c|}{ Geminatization } & \multirow{2}{*}{ Meaning } \\
\hline Gloss & Articulation & \\
\hline$[$ keke'] & {$[$ kekke' $]$} & Bite \\
\hline$[$ ma'lingka $]$ & {$[$ ma'likka $]$} & Walk \\
\hline$[$ mengkayok $]$ & {$[$ mekkayok $]$} & Scratch \\
\hline$[$ mangkali $]$ & {$[$ makkali $]$} & Dig \\
\hline$[$ marengko $]$ & {$[$ marekko $]$} & Dry \\
\hline
\end{tabular}

Figure 3. Geminatitation /k/ becomes /kk/

\section{CONCLUSION}

Being based on the results of the above exposure can be concluded bajawa in Toraja in the Tana Toraja region, there is geminatization / $\mathrm{t} / \mathrm{become} / \mathrm{tt} /$ for example in the words lettek, kalitting, mettia' mattanan, mettiro, mattunu, kandotti' malottong, geminatization / p / become / pp / the word paleppeng, leppang, mangippi, manipping, and geminatization / $\mathrm{k} /$ become / kk / on the word kekke, ma'likka, mekkayok, makkali, marekko'

\section{AUTHORS' CONTRIBUTION}

The drafter of research concepts (Resnita Dewi), data collection (Resnita Dewi and Daud Rodi), data processing and writing of publication manuscripts, manuscript publication process (Resnita Dewi and Daud Rodi Palimbong). Role division: Main Contributor (Resnita Dewi), Member Contributor (Daud Rodi Palimbong). 


\section{ACKNOWLEDGMENTS}

Through this opportunity, we thank all those who have helped the implementation of this research, until it can be published. Especially to informants who are willing to provide data.

\section{REFERENCES}

[1] Savitri, A. (2019). Korespondensi Kontoid Geminat dan Distribusinya dalam Bahasa Madura di Kabupaten Situbondo Dan Bondowoso. ARBITRER: Jurnal Pendidikan Bahasa Dan Sastra Indonesia, 1(3), 149-166.

[2] Mahsun. (1995). Dialektologi Diakronis. Yogyakarta: Gadjah Mada University Press. Muslich. Masnur. (2008). Tata Bentuk Bahasa Indonesia: Kajian ke Arah Tatabahasa Deskriptif. Jakarta: Bumi Aksara.

[3] Pycha, Anne. (2010). "A Test Case for The Phonetics-Phonology Interface: Gemination Restriction in Hungarian”. Phonology. Vol 27 No 1. 2010. Ed. Collin J Ewwen dan Ellen Keissen: 119152.

[4] Zainudin, Sodaqoh dkk. (1978). Bahasa Madura. Jakarta: Pusat Pembinaan dan Pengembangan Bahasa Depdiknas.

[5] Mahsun. (2005). Metode Penelitian Bahasa. Jakarta : Raja Grafindo Persada

[6] Arikunto, Suharsimi. (2006). Prosedur Penelitian Suatu Pendekatan Praktik, Jakarta: Rineka Cipta

[7] Sofyan, Akhmad. (2008). Variasi, Keunikan, dan Penggunaan Bahasa Madura. Sidoarjo: BBJT Pusat Bahasa Depdiknas. 